\title{
Relationship between peroxisome proliferator-activated receptor- $\gamma$ and renal ischemia-reperfusion injury
}

\author{
MASAHIDE MATSUYAMA ${ }^{1,4}$, RIKIO YOSHIMURA ${ }^{1}$, YUTAKA KAWAHITO ${ }^{2}$, HAJIME SANO $^{3}$, \\ JAMEL CHARGUI $^{4}$, JEAN-LOUIS TOURAINE $^{4}$ and TATSUYA NAKATANI ${ }^{1}$
}

\author{
${ }^{1}$ Department of Urology, Osaka City University Graduate School of Medicine, 1-4-3 Asahi-machi, \\ Abeno-ku, Osaka 545-8585; ${ }^{2}$ Department of Inflammation and Immunology, Graduate School of Medical Science, \\ Kyoto Prefectural University of Medicine, 465 Kajiicho, Kawara-machi, Kamigyou-ku, Kyoto 602-0841; \\ ${ }^{3}$ Department of Internal Medicine, Hyogo College of Medicine, 1-1 Mukogawa-cho, Nishinomiya, Hyogo 663-8501, \\ Japan; ${ }^{4}$ Department of Transplantation and Clinical Immunology, Claude Bernard University of Lyon \\ and Lyon Hospitals, Pavillion P, Hôpital Edouard Herriot, Lyon Cedex 3 69437, France
}

Received February 29, 2008; Accepted April 15, 2008

\begin{abstract}
The pathogenesis of ischemia-reperfusion (I/R) injury is known to involve cytokines and, in particular, surface adhesion molecules, the expression of which initiates inflammatory cell attachment. It has been suggested that peroxisome proliferator-activated receptor (PPAR) $-\gamma$ is an important immunomodulatory factor as well as a regulator of fatty acid. In this study, we investigated the expression of PPAR- $\gamma$ in a renal I/R injury rat model. The right kidney was harvested and the left renal artery and vein were clamped by means of a laparotomy. The kidney was reperfused following $90 \mathrm{~min}$ of ischemia. Rats were sacrificed at $0,1.5,3,5,12$ and $24 \mathrm{~h}$ after reperfusion. PPAR- $\gamma$ expression was analyzed by immunohistochemical staining using monoclonal antibody. PPAR- $\gamma$ staining was weak in the endothelial cells, interstitial cells and collecting ducts in the normal kidney. From 1.5 to $5 \mathrm{~h}$ after reperfusion, PPAR- $\gamma$ staining was strong. Twelve hours after reperfusion, necrosis had extended throughout the kidney, and nearly all the tubular epithelial cells were destroyed. However, $12 \mathrm{~h}$ after reperfusion, PPAR- $\gamma$ staining was weak in the endothelial cells and its expression was moderate in the interstitial cells and collecting ducts. PPAR- $\gamma$ was induced in the endothelial cells, including the mesangial cells, interstitial cells and collecting ducts in a rat model of renal I/R injury.
\end{abstract}

\section{Introduction}

Renal transplantation is an acceptable therapeutic approach for patients with end-stage renal disease. Renal ischemia-

Correspondence to: Dr Rikio Yoshimura, Department of Urology, Osaka City University Hospital, 1-4-3 Asahi-machi, Abeno-ku, Osaka 545-8585, Japan

E-mail: jasmin@med.osaka-cu.ac.jp

Key words: peroxisome proliferator-activated receptor- $\gamma$, renal ischemia-reperfusion injury, immunohistochemistry reperfusion (I/R) injury is a clinically significant problem and an invariable consequence of renal transplantation that results from aortic cross-clamping and resuscitation after systemic hypotension. Previous studies have focused on the function of neutrophils, the action mechanisms of inflammatory cytokines, tissue factors, intercellular adhesion molecule-1, oxygen-free radicals, vascular plugging, edema and other complications (1).

Peroxisome proliferator-activated receptors (PPARs) are members of the nuclear hormone receptor superfamily of ligand-activated transcriptional factors, which includes receptors for steroids, thyroid hormones, vitamin $\mathrm{D}_{3}$ and retinoic acid. PPAR binds to a peroxisome proliferator responsive element to form a heterodimer with the retinoic receptor in the regulation of PPAR target genes (2).

There are three known PPAR isoforms: PPAR- $\alpha,-\beta$ and $-\gamma$. PPAR- $\alpha$ primarily regulates the fatty acid metabolism and has an anti-inflammatory effect; its ligands are used in fibrate drugs. PPAR- $\beta$ is ubiquitously expressed throughout the body, but its physiological functions are unknown. PPAR- $\gamma$ has anti-inflammatory effects and controls the functioning of the immune system, having inhibitory action on the production of nitric oxide, cytokine and monocyte chemoattractant protein-1 and on B-cell growth, vascularization and cell growth, and differentiation-inducing action on dendritic cells and helper T-cells (3).

PPAR $-\gamma$ has also been implicated in inflammation and tumorigenesis (4), and significant evidence from many experimental models suggests that it plays a role in carcinogenesis. We demonstrated that PPAR- $\gamma$ is upregulated in malignant tissue, and that its ligands induce terminal differentiation in human urological cancers, inhibiting their growth (4-7). However, few reports have addressed the relationship between PPAR $-\gamma$ and renal I/R injury. For this reason, we investigated their relationship in a rat model.

\section{Materials and methods}

Ischemia-reperfusion model. Male Lewis rats (180-230 g) were used. During a laparotomy using pentobarbital sodium 

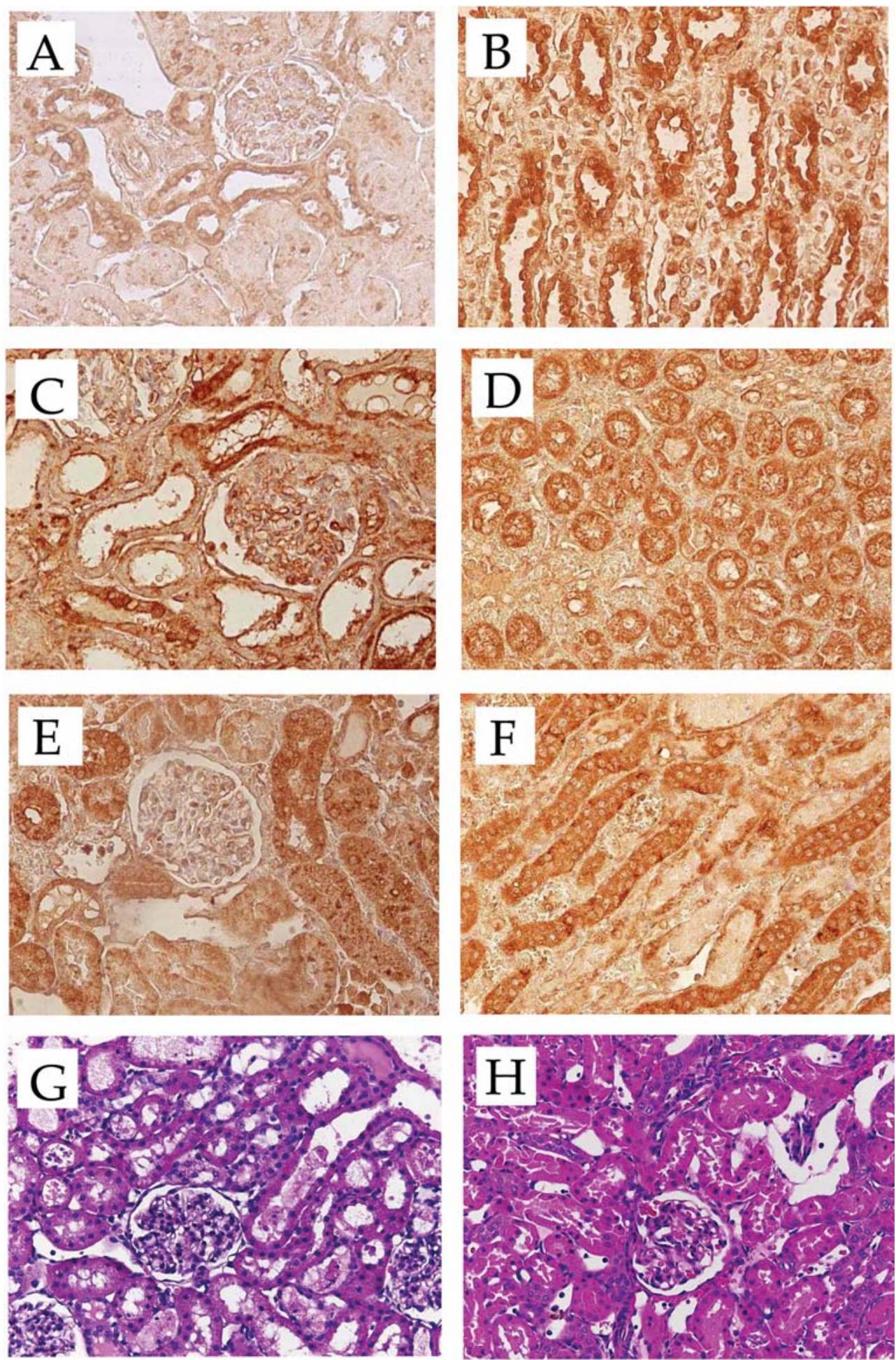

Figure 1. PPAR- $\gamma$ immunohistochemistry and H\&E staining. In the normal kidney, PPAR- $\gamma$ staining was weak in the endothelial cells, including the mesangial cells (A), weak in the interstitial cells and strong in the collecting ducts of the medulla (B). From 1.5 to $5 \mathrm{~h}$ after reperfusion, PPAR- $\gamma$ staining was strong in the endothelial cells (C), moderate in the interstitial cells and strong in the collecting ducts (D). It was, however, weak in the tubules (C). Five hours after reperfusion, the internal spaces of the tubular epithelial cells were expanded and slight destruction of the tubular epithelial cells was apparent (G). The necrotic area extended and encompassed nearly all of the ischemic kidney within $12 \mathrm{~h}$ after reperfusion $(\mathrm{H})$. At $12 \mathrm{~h}$ after reperfusion, PPAR- $\gamma$ staining was weak in the endothelial cells (E), moderate in the interstitial cells and strong in the collecting ducts (F).

anesthesia, the right kidney was harvested and the left renal artery and vein were clamped with a hemostasis clip for $90 \mathrm{~min}$. The clip was subsequently removed to permit reperfusion, and the abdomen was closed during I/R. The rats were sacrificed at $0,1.5,3,5,12$ and $24 \mathrm{~h}$ after reperfusion, and their kidneys harvested. Samples of ischemic and non- ischemic kidney tissue were fixed in $10 \%$ buffered formalin for $24 \mathrm{~h}$ for immunohistochemistry and $\mathrm{H} \& \mathrm{E}$ staining.

Immunohistochemical staining. Immunohistochemical staining was performed with the Vectastatin avidin-biotin peroxidase complex kit (Vector Laboratories, Burlingame, CA, USA). 
Table I. Statistical analysis of PPAR- $\gamma$ expression and acute tubular necrosis score.

\begin{tabular}{lccr}
\hline Time after reperfusion injury & PPAR- $\gamma$ of the renal cortex & PPAR- $\gamma$ of the renal medulla & ATN \\
\hline $0 \mathrm{~h}$ & $1.5 \pm 0.5$ & $3.0 \pm 0.7$ & $0.1 \pm 0.2$ \\
$1.5 \mathrm{~h}$ & $3.4 \pm 0.6^{\mathrm{a}}$ & $3.4 \pm 0.6$ & $0.2 \pm 0.3$ \\
$3.0 \mathrm{~h}$ & $3.2 \pm 0.7^{\mathrm{a}}$ & $3.5 \pm 0.6$ & $0.6 \pm 0.4$ \\
$5.0 \mathrm{~h}$ & $2.8 \pm 0.7^{\mathrm{a}}$ & $3.3 \pm 0.5$ & $1.2 \pm 0.4$ \\
$12.0 \mathrm{~h}$ & $2.2 \pm 0.8$ & $3.4 \pm 0.5$ & $2.5 \pm 0.4$ \\
$24.0 \mathrm{~h}$ & $1.7 \pm 0.8$ & $3.3 \pm 0.6$ & $2.9 \pm 0.3$ \\
Before ischemia & $1.2 \pm 0.7$ & $2.9 \pm 0.6$ & N.P. \\
\hline
\end{tabular}

The acute tubular necrosis (ATN) score was graded as 0-3 on coded sections by two observers in a blinded manner. 0 , no destruction; 3 , maximun destruction. The PPAR- $\gamma$ score was graded as 0-4 on coded sections by two observers in a blinded manner. 0 , no staining; 4 , maximum intensity. Statistical analysis was performed using the analysis of variance (ANOVA); ${ }^{\mathrm{a}} \mathrm{p}<0.01$. Values represent the men \pm SD.

Kidney tissues sectioned onto microscope slides were deparaffinized. The slides were immersed for $45 \mathrm{~min}$ in $0.3 \%$ peroxide in methanol to deplete endogenous peroxidase activity. Non-specific binding sites were saturated with $0.2 \%$ bovine serum albumin and normal goat serum diluted to 1:66.7 in PBS for 20 min. Primary antibodies against goat PPAR- $\gamma$ (Santa Cruz, CA, USA) (1:50 dilution in PBS), or control normal goat serum (Vector Laboratories) were used at a dilution of 1:50, applied to tissue sections and incubated in a humidified chamber at room temperature for $30 \mathrm{~min}$. The sections were then washed with PBS for 10 min. Biotinylated rabbit anti-goat $\operatorname{IgG}$ (Vector Laboratories) was applied to the tissue sections, which were then incubated at room temperature for $30 \mathrm{~min}$. After washing with PBS for $10 \mathrm{~min}$, the slides were incubated with avidin DH-biotinylated peroxidase (Vector Laboratories) for $45 \mathrm{~min}$. Finally, the color was developed by immersion of the sections in a peroxidase substrate solution including $0.02 \%$ peroxide, $3,3^{\prime}$ diaminobenzine tetrahydrochloride, $0.04 \%$ nickel chloride and $0.01 \%$ hydrogen peroxide in $0.05 \mathrm{M}$ Tris- $\mathrm{HCl}, \mathrm{pH} 7.2$, for 2-7 min. The sections were counterstained with hematoxylin (Sigma, St. Louis, MO, USA).

Analysis of acute tubular necrosis and PPAR-y expression score. To quantify the degree of acute tubular necrosis (ATN), a scale of 0-3 was assigned by two observers in a blinded manner on two separate occasions using coded slides. The average of the scores was evaluated, and the degree of ATN was defined as: no, mild, moderate or severe necrosis. Necrosis, capillary congestion, interstitial edema, cast, destruction, and flat and extended areas of tubular epithelial cells were also evaluated. Similarly, PPAR- $\gamma$ expression was classified in the renal cortex and renal medulla. PPAR- $\gamma$ staining was graded on a scale of 0-4 according to the intensity of staining, with a score of 4 considered to be maximum. The same two pathologists assessed ATN and PPAR- $\gamma$ expression throughout the study.

Stastistical analysis. All results are presented as the means \pm standard deviation. Analysis of the data was performed using the analysis of variance (ANOVA) (8).

\section{Results}

$H \& E$ and immunohistochemical staining of PPAR- $\gamma$. In the normal kidney, PPAR- $\gamma$ staining was weak in the endothelial cells, including the mesangial cells (Fig. 1A). On the other hand, PPAR- $\gamma$ staining was weak in the interstitial cells and strong in the collecting ducts of the medulla (Fig. 1B). From 1.5 to $5 \mathrm{~h}$ after reperfusion, PPAR- $\gamma$ staining was strong in the endothelial cells including mesangial cells (Fig. 1C), moderate in the interstitial cells and strong in the collecting ducts (Fig. 1D). However, PPAR- $\gamma$ staining was weak in the tubules (Fig. 1C). Five hours after reperfusion, the internal spaces of the tubular epithelial cells were expanded, and slight destruction of the tubular epithelial cells was apparent (Fig. 1G). The necrotic area extended and encompassed nearly all of the ischemic kidney within $12 \mathrm{~h}$ after reperfusion (Fig. 1H). Twelve hours after reperfusion, PPAR- $\gamma$ staining was weak in the endothelial cells (Fig. 1E), moderate in the interstitial cells and strong in the collecting ducts (Fig. 1F). However, PPAR- $\gamma$ staining was very weak in the proximal tubules, distal tubules and necrotic tubules at each time point after reperfusion.

Statistical analysis of PPAR- $\gamma$ expression and acute tubular necrosis score. ATN scores $(0 \mathrm{~h}, 0.1 \pm 0.2 ; 1.5 \mathrm{~h}, 0.2 \pm 0.3 ; 3 \mathrm{~h}$, $0.6 \pm 0.4 ; 5 \mathrm{~h}, 1.2 \pm 0.4 ; 12 \mathrm{~h}, 2.5 \pm 0.4 ; 24 \mathrm{~h}, 2.9 \pm 0.3$ ) were gradually higher at time flow after reperfusion. PPAR- $\gamma$ scores of the renal cortex $(0 \mathrm{~h}, 1.5 \pm 0.5 ; 1.5 \mathrm{~h}, 3.4 \pm 0.6 ; 3 \mathrm{~h}$, $3.2 \pm 0.7 ; 5 \mathrm{~h}, 2.8 \pm 0.7 ; 12 \mathrm{~h}, 2.2 \pm 0.8 ; 24 \mathrm{~h}, 1.7 \pm 0.8$; nonischemia: $1.2 \pm 0.7$ ) were significantly higher at $1.5,3$ and $5 \mathrm{~h}$ after reperfusion than at 0,12 and $24 \mathrm{~h}$ after reperfusion. PPAR- $\gamma$ scores in the renal medulla $(0 \mathrm{~h}, 3.0 \pm 0.7 ; 1.5 \mathrm{~h}$, $3.4 \pm 0.6 ; 3$ h, $3.5 \pm 0.6 ; 5$ h, $3.3 \pm 0.5 ; 12$ h, $3.4 \pm 0.5 ; 24$ h, $3.3 \pm 0.6$, non-ischemia: $2.9 \pm 0.6$ ) were higher than PPAR- $\gamma$ scores in the renal cortex (Table I).

\section{Discussion}

Renal I/R injury is a clinically significant problem and an invariable consequence of renal transplantation involving the 
onset of acute tubular necrosis. This occurs when transplantation is prolonged by a long ischemic interval due to the use of a kidney from a cardiac arrest donor. The longer the ischemic interval, the higher the incidence rate of ATN. The reduction of I/R injury (3) is thus of extreme clinical importance.

$\mathrm{I} / \mathrm{R}$ injury is best alleviated by the blocking of macrophagederived cytokines such as tumor necrosis factor- $\alpha$ and interleukin-1, which are abundant in I/R injury tissues. PPAR- $\gamma$ ligands in part inhibit the expression of nitric oxide, cytokines such as tumor necrosis factor- $\alpha$ and interleukin-1, chemokines and adhesion molecules by antagonizing the activities of transcription factors such as activator protein-1 and nuclear factor- $\mathrm{kB}$. Among the inducible transcription factors involved in I/R injury, intercellular adhesion molecule-1 and nuclear factor-кB play important roles (2).

Several reports have demonstrated the efficacy of PPAR- $\gamma$ ligands in renal I/R injury. Naito et al demonstrated that the PPAR- $\gamma$ ligand pioglitazone ameliorated reperfusion-induced intestinal injury in rats and inhibited the increase in neutrophil accumulation associated with tumor necrosis factor- $\alpha$ expression (9). Sivarajah et al demonstrated that the PPAR- $\gamma$ ligands rosiglitazone and ciglitazone reduced the renal dysfunction and injury associated with I/R of the kidney (10). Yue et al demonstrated that rosiglitazone reduced myocardial infarction and improved contractile dysfunction caused by I/R injury (11). Besides I/R injury, Buckingham et al demonstrated that the PPAR- $\gamma$ ligand rosiglitazone protected against nephropathy and pancreatic islet abnormalities in rats (12). However, there have been no reports on the correlation between the progression of time and PPAR- $\gamma$ expression in I/R injury.

Generally, PPARs modulate the activities of different immune cell types, such as monocytes/macrophages, lymphocytes and endothelial cells. Braissant et al demonstrated that PPAR $-\gamma$ is highly expressed in hepatocytes, cardiomyocytes, enterocytes and the proximal tubule cells of the kidney. PPAR- $\beta$ is expressed ubiquitously and often at higher levels than PPAR $-\alpha$ or $-\gamma$. PPAR $-\gamma$ is predominantly expressed in the adipose tissue and the immune system of rats (13). Kawahito et al found markedly enhanced expression of PPAR- $\gamma$ in macrophages, as well as modestly enhanced expression in the synovial lining layer, fibroblasts and endothelial cells in a rat adjuvant-induced arthritis model, in which PPAR- $\gamma$ was localized predominantly to the perinuclear legion and the cytoplasm (2). Using RT-PCR, Yang et al demonstrated that PPAR- $\gamma$ was abundant in the renal inner medulla and localized to the inner medullary collecting duct and renal medullary interstitial cells in normal kidney tissues (14). Iwashima et al, also using RT-PCR, demonstrated that PPAR- $\gamma$ was expressed in cultured mesangial cells (15). Asano et al found that PPAR- $\gamma$ was expressed in rat mesangial cells and that its differentiation was modulated by PPAR- $\gamma$ ligands (16). Besides I/R injury, Paueksakon et al demonstrated that PPAR- $\gamma$ expression was increased in areas of sclerosis in arteries and glomeruli, with expression of both in glomerular mesangial, parietal and visceral epithelial cells. Infiltrating macrophages in glomeruli were PPAR $-\gamma$ negative, in contrast with their positivity in macrophages, in control cases of carotid artery plaque and in renal interstitial macrophages by immunostaining in human diabetic nephropathy (17).
In the present study, we found PPAR- $\gamma$ to be strongly expressed in the collecting ducts, interstitial cells and endothelial cells including mesangial cells. The extent and intensity of PPAR- $\gamma$ in these cells in the renal cortex were most intense 1.5-5 $\mathrm{h}$ after renal I/R injury. Twelve hours after renal I/R injury, we found that PPAR- $\gamma$ was weakly expressed in these cells. In the tubules, PPAR- $\gamma$ was weakly expressed at each time point after renal I/R injury. On the other hand, PPAR- $\gamma$ expression in the renal medulla was strong at each time point after renal I/R injury and in the normal kidney. These results suggest that the relationship between PPAR- $\gamma$ and renal I/R injury is stronger in the renal cortex than in the renal medulla.

It is possible, therefore, that PPAR $-\gamma$ ligands control PPAR- $\gamma$ expression in the collecting ducts, interstitial cells and endothelial cells including mesangial cells in renal $\mathrm{I} / \mathrm{R}$ injury. In conclusion, PPAR- $\gamma$ is induced in the endothelial cells including the mesangial cells, in the interstitial cells and in the collecting ducts in a rat model of renal I/R injury.

\section{Acknowledgements}

The authors thank Hilah Edney, B.S., M.S. for editorial assistance.

\section{References}

1. Matsuyama M, Yoshimura R, Akioka K, Okamato M, Ushigome H, Kadotani Y, Nakatani T and Yoshimura N: Tissue factor antisense oligonucleotides prevent renal ischemia-reperfusion injury. Transplantation 76: 786-791, 2003.

2. Kawahito Y, Kondo M, Tsubouchi Y, Hashiramoto A, BishopBailey D, Inoue K, Kohno M, Yamada R, Hla T and Sano H: 15-deoxy-PGJ 2 induces synoviocyte apotosis and supresses adjuvant-induced arthiritis in rats. J Clin Invest 106: 189-197, 2000.

3. Matsuyama M and Yoshimura R: Prospects of antisense treatment to alleviate renal ischemia-reperfusion injury. Expert Opin Biol Ther 4: 1931-1937, 2004.

4. Inoue K, Kawahito Y, Tsubouchi Y, Kohno M, Yoshimura R, Yoshikawa T and Sano H: Expression of peroxisome proliferatoractivated receptor gamma in renal cell carcinoma and growth inhibition by its agonists. Biochem Biophys Res Commun 287: 727-732, 2001.

5. Yoshimura R, Matsuyama M, Segawa Y, Hase T, Mitsuhashi M, Tsuchida K, Wada S, Kawahito Y, Sano H and Nakatani T: Expression of peroxisome proliferator-activated receptors (PPARs) in human urinary bladder carcinoma and growth inhibition by its agonists. Int J Cancer 104: 597-602, 2003.

6. Segawa Y, Yoshimura R, Hase T, Nakatani T, Wada S, Kawahito Y, Kishimoto $\mathrm{T}$ and Sano H: Expression of peroxisome proliferatoractivated receptor (PPAR) in human prostate cancer. Prostate 51: 108-116, 2002.

7. Hase T, Yoshimura R, Mitsuhashi M, Segawa Y, Kawahito Y, Wada S, Nakatani T and Sano H: Expression of peroxisome proliferator-activated receptors in human testicular cancer and growth inhibition by its agonists. Urology 60: 542-547, 2002.

8. Fitzgerald SM and Flinn S: Evaluating research studies using the analysis of variance (ANOVA): issues and interpretations. $\mathbf{J}$ Hand Ther 13: 56-60, 2000.

9. Naito Y, Takagi T, Uchiyama K, Handa O, Tomatsuri N, Imamoto E, Kokura S, Ichikawa H, Yoshida $\mathrm{N}$ and Yoshikawa T: Suppression of intestinal ischemia-reperfusion injury by a specific peroxisome proliferator-activated receptor-gamma ligand, pioglitazone, in rats. Redox Rep 7: 294-299, 2002.

10. Sivarajah A, Chatterjee PK, Patel NS, Todorovic Z, Hattori Y, Brown PA, Stewart KN, Mita-Filipe H, Cuzzocrea S and Thiemermann C: Agonists of peroxisome-proliferator activated receptor-gamma reduce renal ischemia/reperfusion injury. Am J Nephrol 23: 267-276, 2003. 
11. Yue T-L, Chen J, Bao W, Narayanan PK, Bril A, Jiang W, Lysko PG, Gu J-L, Boyce R, Zimmerman DM, Hart TK, Buckingham RE and Ohlstein EH: In vivo myocardial protection from ischemia/reperfusion injury by the peroxisome proliferatoractivated receptor-gamma agonist rosiglitazone. Circulation 104: 2588-2594, 2001.

12. Buckingham RE, Al-Barazanji KA, Toseland CD, Slaughter M, Connor SC, West A, Bond B, Turner NC and Clapham JC: Peroxisome proliferator-activated receptor-gamma agonist, rosiglitazone, protects against nephropathy and pancreatic islet abnormalities in Zucker fatty rats. Diabetes 47: 1326-1334, 1998.

13. Braissant O, Foufelle F, Scotto C, Dauca M and Wahli W: Differential expression of peroxisome proliferator-activated receptors (PPARs): tissue distribution of PPAR-alpha, -beta, and -gamma in the adult rat. Endocrinology 137: 354-366, 1996.
14. Yang T, Michele DE, Park J, Smart AM, Lin Z, Brosius FC III, Schnermann JB and Briggs JP: Expression of peroxisomal proliferator-activated receptors and retinoid $X$ receptors in the kidney. Am J Physiol 277: 966-973, 1999.

15. Iwashima Y, Eto M, Horiuchi S and Sano H: Advanced glycation end product-induced peroxisome proliferator-activated receptor gamma gene expression in the cultured mesangial cells. Biochem Biophys Res Commun 264: 441-448, 1999.

16. Asano T, Wakisaka M, Yoshinari M, Iino K, Sonoki K, Iwase M and Fujishima M: Peroxisome proliferator-activated receptor gamma1 (PPARgamma1) expresses in rat mesangial cells and PPARgamma agonists modulate its differentiation. Biochim Biophys Acta 1497: 148-154, 2000.

17. Paueksakon P, Revelo MP, Ma LJ, Marcantoni C and Fogo AB: Microangiopathic injury and augmented PAI-1 in human diabetic nephropathy. Kidney Int 61: 2142-2148, 2002. 